\title{
Translation Analysis of Swear Words in The Wolf of Wall Street Movie
}

\author{
Dwi Wulan Sari \\ Postgraduate Student of Translation Studies, Gunadarma University, Jl. Margonda Raya 100, Depok West Java, \\ 16424 Indonesia
}

\begin{abstract}
Swear words are used in daily conversation with their own intention but there will be a problem when it comes to translate the swear words into other language due to the differences of culture. The translator should adjust his/her translation to the culture of the target language. The rate of politeness is also an aspect which should be concerned in translating swearwords especially in Asian countries like Indonesia. Several experts have proposed some translation theories to solve this problem. This descriptive research aims to analyze what strategies used in translating swear words in The Wolf of Wall Street movie. The data taken for this study is the English transcription and its Indonesian subtitle of the movie. There are 35 data obtained for this analysis are from The Wolf of Wall Street movie. This study employed descriptive qualitative method within the parameter of case study. The results of this study showed that there are three strategies used in translating swear words; Syntactic Strategy, Semantic Strategy and Pragmatic Strategy.
\end{abstract}

Keywords: swear words, translation, strategy

DOI: $10.7176 / J L L L / 54-07$

Publication date:March $31^{\text {st }} 2019$

\section{INTRODUCTION}

Different people use different language styles in their day-to-day communication eventhough in the same language. They tend to use informal language in casual conversation. It also can be seen in some movies which show how people speak in their own way sich as in the most popular movie that is American movies. It provides any kind of movie genres with interesting story plot. Comedy movie seems to be the favourite one for movie lovers to watch. By watching this movie, they can simply entertain their selves through the funny story.

In comedy movie, swear words appear many times as in this movie the language used is informal or daily language. Swear words are spoken with some intentions according to its context but mostly people used it as an exclamation or to show their expiration.

For foreigner viewers, they need subtitle to understand the movie well including the swear words spoken in it. Subtitle is an important aspect in a movie. Subtitling is something to do with translation process due the subtitle is produced to transfer the dialogue that is spoken in source language into target language in the form of written text. The translator must be able to deliver the message, emotion and the sense to the viewers including when there is an inappropriate word such as swearwords in the movie. As said by Shuttleworth and Cowie (1997 in Ghaemi \& Benyamin, 2010), "As the process of providing synchronized captions for film and television dialogue ".

Nevertheless the translator should be careful in translating swear words as it may be impolite if it is literally translated to the target language. The translator has to consider the culture and norm values yet he/she should deliver the message appropriately. In translating swear words, there are several strategies of translation that can help them in transferring the meaning to the target language.

A number of studies about swear words have been conducted by some researchers such as Minna Hjort (2009) who analyzed swearwords in Finnish subtitle. She found that the translations often have milder and less swearwords than the original shows and films. An analysis of swear words in movie subtitle has been carried out by Chong Han and Kenny Wang (2014) They concluded that in translating English swear words into Chinese language; the communicative function of the source text is retained though it caused shifting in the translation. Elizabeth Marsde (2009, in her study, stated that swear words can be spoken in casual conversation such as in joking. This study aims to analyse the translation strategies used in translating swear words in subtitle into Indonesian language.

\section{METHOD}

The researcher employed descriptive method. As being said by Suryawinata \& Hariyanto this research aims only to describe the important phenomenon in this research (2003). In doing this method of the research, the researcher collected the data, classified, analyzed, and then draw conclusion based on the data Hadi(1983).

As mentioned before, this research was categorized into qualitative research since the data were stated in the form of words or sentences Arikunto (1997). In line with Arikunto's statement, Miles and Huberman ( in Creswell 2003) stated that the most frequent form of data display for qualitative research data has been in 
descriptive, narrative form.

Data source is the object from which the data are selected for the research. Data source has an important role in providing the information needed by the researcher. Djajasudarma states that the data can be obtained from scripts, interviews, photographs, videotapes, personal documents, etc. (1993).

The data of this research is The Wolf of Wall Streettanscription and its Indonesian subtitle, strategies used in the subtitling. This movie is chosen because as stated at www.guinnessworldrecords.com that " ... The Wolf of Wall Street has set a new Guinness World Records record title for most swearing in one film" with 506 times the appearance of the word fuck. Moreover, it takes 180 minutes. to watch this movie till the end while the other movies ended in 120 minutes.

To analyze the data, the reseacher first watched the movie to find any utterance that contained swearwords. After that the reseacher compared the English transcription to the Indonesian. Then founding the data the reseacher identified the data according to its translation strategy. Then, conclusion was drawn at the end of the analysis.

\begin{abstract}
ANALYSIS
There are 711 swear words appeared in this movie but the researcher carried out 35 data for this analysis as from the data there are 506 times the appearance of the word fuck and 94 repetitions of the word shit. The swearing words are marked in bold to make it easier to be recognized while for the translation of these words were in italic form. In the following section, each data is analyzed according to its translation strategy. ST refers to the source text which is the transcription of the movie while the TT refers to the target text which s its Indonesian subtitle.
\end{abstract}

\title{
SYNTACTIC STRATEGY
}

After analyzing the data obtained, the analysis reveals that there is one syntactic strategy used in translation bastard in the subtitle namely literal translation. There are three data found that is literally translated as follows: Data 1 (ass)

ST: We would wipe our ass with it.

TT: Kami akan membersihkan bokong kami dengan itu.

The word ... ass... is translated into ...bokong... which is its literal meaning. The translator translates it using literal strategy as in this context; the speaker was talking about papier toilet. Papier toilet is used to clean or wipe our body part after using the toilet. In this data, the speaker were talking about U.S. Justice Department that was going to send him a subpoena but he told that he wanted to use it as a paiper toilet. The word ... ass... is used as a bastard to show his disgust. In formal way, instead of saying ass somebody can use the word buttock to refer to our lower body part.

Data 2 (bitch)

ST: Quit your bitching.

TT: Berhenti mengeIuh.

The word ... bitching... is translated into ... mengeIuh... According to Dictionary of American Slang and Colloquial Expression the word ... bitching... means to complain. The translator translates it using literal strategy. The word ... bitching... is included as a bastard. The speaker used the word ... bitching... to show his anger.

Data 3 (ass)

ST: and move your ass! Please.

TT: gerakkan tubuhmu!

In the data above, the word bastard... ass... is translated into ...tubuhmu... The word ...ass... according to Dictionary of American Slang and Colloquial Expression means one's whole body. The translator translates it literally as in this context; the speaker used this word to ask someone to move his body.

\section{SEMANTIC STRATEGY}

Semantic strategy appears as the most used strategy in this analysis with three strategies employed by the translator in translating the subtitle in this movie. These strategies are Synonymy, Distribution Change, Paraphrase and Other Semantic Change. There are 20 out of 40 data found in this strategy. The followings are example of data which use semnatic strategy:

The first semantic strategy used is synonymy. There are four data found that used synonym in the subtitle. 
The translator uses synonym to translate the target text because the word cannot literally translated or he/she does not find the equivalence of the words therefore the translator use synonym as the closest equivalence. The used of this strategy can be seen in the example below:

Data 1 (shit)

ST: You American shit!

TT: Kau orang Amerika sial!.

In data 1 , the word ...shit... which is a bastard is translated into ...sial.... The word ...shit..., according to Dictionary of American Slang and Colloquial Expression means a wretched person and if it is literally translated then it becomes bedebah. Here, the translator translates it into ...sial.... which is the synonym for the word bedebah.

Data 2 (shit)

\section{ST: you piece of shit!}

TT: kau bajingan!

The swear word bastard ...shit... appears in the source text and it is translated into ...bajingan.... The speaker used the word ...shit... to call a wretched person. The word ...shit..., if it is literally translated then it becomes bedebah but the translator translates it into ...bajingan.... which is the synonym for the word bedebah.

Other semantic strategy used is this analysis is Distribution Change that appears the most with 13 data found. Distribution Change is used to reduce the target text because the word is not necessary to be translated. The followings are the example of Distribution Change found in the data:

Data 1 (fuck)

ST: You can save the fucking spotted owl with money.

TT: Kau bisa menyeIamatkan burung hantu bertutuI dengan uang.

The word ...fucking... is omitted in the target text as it is not necessary for the translator to translate this word. In adition the translator does not translate the word ...fucking... since the way of the speaker speaks has already helped the viewers to understand the whole meaning of the source text. In this context, the word fuck is used to emphasize the sentence.

Data 2 (motherfucker)

ST: In. In. Shut that motherfucker.

TT: Masukkan. Masukkan. Tutup itu.

In this sentence, the word ...motherfucker... is not translated as in this context the word ...motherfucker... is used as an exclamation but the situation of the conversation is casual. So the translator does not need to translate it since the message of the target text has been already delivered well.

Data 2 (bitch)

ST: Shut up, you little bitch!

TT: Tutun muIutmu!

As can be seen from the example above, the word ...bitch is omitted in the target text. The word ...bitch is used to call an unpleasant female. In this context, the translator does not need to translate it because the viewers can clearly acknowledged whom the speaker talked to.

The third semantic strategy used in this analysis is Paraphrase. According to Chesterman (2000) "This is a typical strategy for translation of idioms, for instance, for which no corresponding idiomatic expression can be found in the TL." The researcher found one datum that used paraphrase in the subtitle. Below is the example of the data:

Data 1 (fuck)

ST: Your little friend is trying to fuck me right in the ass.

TT: Donnie, temanmu berusaha mengacaukanku, kau tahu itu.

As can be seen from the example above, the word ...fuck me... is an English idiom and is translated into ...mengacaukan.... The translator translates it into non idiomatic expression by using paraphrase strategy. The idiom ...fuck me... itself according to Oxford Advanced Learner's Dictionaries used to express surprise. 
The last semantic strategy found this analysis is Other Semantic Change. After analyzing the data obtained, the reseacher found one data that is translated using Other Semantic Change. The following is the data:

Data 1 (shit)

\section{ST: I shit you not, it exploded}

TT: Aku tak bercanda, itu meIedak

In the data above, the bastard ...shit... is translated into ...bercanda... The word ...shit...can means to deceive someone and if it is literally translated the translation becomes menipu but here the translator translates it into ...bercanda.... that caused semantic change in the target text. ...bercanda.... according to Kamus Besar Bahasa Indonesia means 1 bertingkah; 2 berkelakar; bersenda gurau; berseloroh.

\section{PRAGMATIC STRATEGY}

In this analysis, to translate bastard, the translator also used Pragmatic Strategy. Chesterman (2000) stated that if syntactic strategies manipulate form, and semantic strategies manipulate meaning, pragmatic strategies can be said to manipulate the message itself. The pragmatic strategy used in this data is Cultural Filtering. The reseacher obtained 9 data that used Cultural Filtering Strategy. There are the examples of the data, namely:

Data 1 (fuck)

\section{ST: Fuck the clients.}

TT: Persetan para kIien.

In the example above, the word ...fuck... that is used as exclamation of anger is translated into ...persetan....In English Indonesian Bilingual Dictionary, there is not word ...fuck... but in this nontext, the speaker used the word fuck to show that he hated everything related to the clients. The word ...persetan.... itself is used the same way as the word fuck.

Data 2 (Holy Fuck)

ST: Holy fuck, you did just say that.

TT: SiaI, kau baru saja mengatakan itu.

The phrase Holy fuck...that is used as exclamation to show exsperation is translated into Sial ....The word Sial .... is not the literal translation of the phrase Holy fuck... but it expresses the equivalent expression in the target language.

Data 3 (Motherfucker)

\section{ST: Fuck that motherfucker!}

TT: Persetan bajingan itu!

The word... motherfucker is translated into persetan ...bajingan... itu in the target text. The word ... motherfucker is not in the English Indonesian Bilingual Dictionary. The bastards motherfucker to call a male in a very rude way as well as the word ...bajingan... in this context, the speaker used this bastard to call his client who is despised.

\section{DISCUSSION}

This descriptive research aims to analyze what strategies used in translating swear word in The Wolf of Wall Street movie. Chesterman (2000) in Memes of Translation mentioned three strategies in translation namely Syntactic Strategies, Semantic Strategies and Pragmatic Strategies. These three strategies are used in translating swear words in this research. Based on the result of the analysis, the uses of these strategies are identified. Table 1 shows the strategies used and the number of data analyzed using each strategy.

TABLE 1. Translation Strategies of Swear Words in The Wolf of Wall Street movie

\section{Translation Strategy}

Syntactic Strategy

Semantic Strategy

Pragmatic Strategy
Literal Translation

Synonym

Distribution Change

Paraphrase

Other Semantic Change

Cultural Filtering

$\begin{array}{cc}\text { No. Swear Words } & \% \\ 3 & 9 \\ 3 & 9 \\ 11 & 31 \\ 1 & 3 \\ 1 & 3 \\ 16 & 45 \\ 35 & 100\end{array}$


The strategy used the most in this research is pragmatic strategy namely cultural filtering. The translator translates the swear words using this strategy due these words cannot be literally translated. In some context, the dictionary does not provide the closest meaning. Therefore, the translator attempted to transfer the meaning of the source text by using any words that is functional equivalent to the orignial words without reducing the nuance of the conversation in the move.

Semantic strategy appears as the second most used strategy in this study. Distribution change found in the translation of swear words more frequent than paraphrase and other semantic change. It possibly happens since the translator should consider the culture and norm of the target language. To make it more polite, sometimes the swear words are omitted in the target text yet the viewers do not lose the entire message of the source text because the visualization and the speaker's way of speaking assist them in understanding the movie. The other strategy used by the translator in this analysis is using synonym of the swear words. This is done to handle some words that do not have eqivalence in the dictionary so the translator choose the closest meaning to it. Paraphrase is used when the swear words is in the form of idiom for the translator translates it into non idiomatic expression. The last semantic strategy used in this study is other semantic change. "These would include other modulation of various kinds, such as change of (phsycal) sense or of deictic direction." Chesterman (2000)

Although swear words mostly translated by maniulating its semantic and pragmatic aspect, in this analysis, the reseacher found that swear words can be translated using syntactic strategy that is literal translation. Literal translation is choosen in translating this word to retain the emotion of the source text.

\section{CONCLUSION}

The main purpose of this study is to analyze the strategy of translation used in translating swear words in The Wolf of Wall Street. This study examined how the translator solve the translation issue in movie subtilte particulary when swear words so many times. This study revealed that swear words are transferred to the target language by considering the cultural aspect.

This analysis revealed that the translator used three translation strategies in dealing with swear words. The concern of this translation is message of the original word itself. The translation should retain the intention, emotion and nuance of the source text. Politeness also an important thing in this translation work since every language has its own norm.

The translator cannot abitrarily translated any swear words but he/she should pay attention to the culture and the norm. Nevertheless, it is not an easy work to be done, translating swear words is still an intersting topic to be studied. Futher researched can be conducted to examine of the translation quality of swear words in particular language.

\section{ACKNOWLEDGE}

The reseacher wishes to acknowledge the help and advise given by Prof. Dr. Ratna Sayekti, Dr. Ichwan Suyudi MM, and Dr. Ahmad Jum'at Khatib Nur Ali, M.Si specially during the research process.

\section{REFERENCE}

Chsterman, A. (2000). Memes of Translation.: Philadelphia: John Benjamins Publishing Company.

Cresswell, John. (1998). Research Design: Qualitative and Quantitative Approaches. London: Sage Publications. Djajasudarma, T.F. (1993). Metode Linguistik, Ancangan Metode Penelitian \& Kajian. Bandung: Penerbit PT. Eresco.

Echols, M. J., \& Shadily, H. (1975). An English-Indonesian Dictionary. New York: Cornell University Press.

Endarmoko, E. (2007). TESAURUS BAHASA INDONESIA. Jakarta: Gramedia.

Ghaemi, Farid and Benyamin, Janin. (2010). "Strategies Used In Translation Of Interlingual Subtitling", Islamic Azad University, Science and Research Branch. Available from: http://www.sid.ir/en/ViewPaper.asp. Accesed at February 2019

Hadi, S. (1983). Methodology Research I: Untuk paper, Skripsi, Thesis \& Desertasi. Yogyakarta: Yayasan Penerbit Fakultas Psikologi UGM.

Han, C., \& Wang, K. (2014). Subtitiling swearwords in Reality TV Series from English into Chinese: A corpusbased study of The Family. The International Journal for Translation \& Interpreting Research, 14.

Hjort, M. (2009). 'Swearwords in Subtitles'. Intralinea. Available at: (Accessed: February 2019)

Marsden, E. (2009). An Analysis of Swearing in Casual Conversation. University of Huddersfield.

Spears, R. R. (2000). NTC's DICTIONARY OF AMERICAK SLANG AND COLOQUIAL EXPRESSIONS. USA: NTC Publishing Group.

Stevens, A. M., \& Telling, A. S. (2004). A Comprehensive Indonesian-English Dictionary. USA: Ohio University Press Athens. 